\title{
Evaluation of role of hyperbilirubinemia as a new diagnostic marker of complicated appendicitis
}

Sabyasachi Bakshi ${ }^{1,2^{*}}$ and Nilay Mandal ${ }^{1}$

\begin{abstract}
Background: In appendicitis, elevated intra-luminal pressure and ischemic necrosis of mucosa causes tissue gangrene or perforation. This leads to cytotoxin facilitated progressive bacterial invasion or translocation into the hepatic parenchyma through portal system. This phenomenon interferes with the bilirubin excretion into the bile canaliculi. In the present study, establishment of a possible role of hyperbilirubinemia as a marker of gangrenous/perforated appendicitis has been studied.
\end{abstract}

Methods: After matching the inclusion and exclusion criteria, all cases of clinically diagnosed acute appendicitis were taken for this prospective, single center, observational study. Per-operative diagnosis was confirmed by histopathological examination.

Results: Out of 110 subjects of acute appendicitis 41 subjects (37.27\%) had hyperbilirubinemia. Out of 35 subjects diagnosed as complicated appendicitis 32 subjects (91.42\%) had raised total bilirubin levels, while the remaining 03 (8.58\%) had normal levels. Among 75 subjects diagnosed as acute simple appendicitis 09 subjects (12\%) had raised total bilirubin level, while the remaining 66 subjects (88\%) had normal levels. It was Mixed Type of Hyperbilirubinemia in gangrenous/perforated appendicitis. The sensitivity of Total serum bilirubin in predicting complicated appendicitis was found $91.43 \%$ (76.942\% to $98.196 \%)$, where as the specificity of this test was $88.00 \%$ (78.439\% to $94.363 \%)$. positive predictive value and negative predictive value were $78.03 \%$ and $95.65 \%$ respectively. Positive likelihood ratio and negative likelihood ratio were found to be 7.619 and 0.097 respectively taking prevalence of complicated appendicitis be 31.80\%. Receiver Operating Characteristic curve was obtained which shows optimal criterion at Total Bilirubin Level $1.06 \mathrm{mg} / \mathrm{dl}$ where sensitivity was $91.43 \%$ and specificity was $97.33 \%$ at $95 \%$ confidence interval with $31.8 \%$ disease prevalence.

Conclusions: This is to conclude that Serum bilirubin level estimation, which is a simple, cheap and easily available laboratory test, can be added to the routine investigations in clinically suspected cases of acute appendicitis for early diagnosis of complications.

Trial registration Registered with Clinical Trials Registry-India (ICMR-NIMS) with Registration number CTRI/2019/05/018879 Dated 01/05/2019. This was a prospective trial. Trial URL: http://ctri.nic.in/Clinicaltrials/pdf_ generate.php?trialid=33113\&EncHid=99780.32960\&modid=1\&compid=19\%27,\%2733113det\%27.

Keywords: Total serum bilirubin, Hyperbilirubinemia, Acute appendicitis, Gangrenous/perforated appendicitis, Ultrasonography, Appendix diameter, Fecolith, Complicated appendicitis

\footnotetext{
*Correspondence: dr.bakshi.s@gmail.com

${ }^{2}$ Kathghara Lane, Sonatuli, PO, Hooghly, West Bengal 712103, India

Full list of author information is available at the end of the article
} original author(s) and the source, provide a link to the Creative Commons licence, and indicate if changes were made. The images or other third party material in this article are included in the article's Creative Commons licence, unless indicated otherwise in a credit line to the material. If material is not included in the article's Creative Commons licence and your intended use is not permitted by statutory regulation or exceeds the permitted use, you will need to obtain permission directly from the copyright holder. To view a copy of this licence, visit http://creativecommons.org/licenses/by/4.0/. The Creative Commons Public Domain Dedication waiver (http://creativeco mmons.org/publicdomain/zero/1.0/) applies to the data made available in this article, unless otherwise stated in a credit line to the data. 


\section{Background}

Hyperbilirubinemia has also been found during some infective diseases involving organs other than liver [1]. Neonates are more susceptible to develop hyperbilirubinemia following gram-negative bacterial infections. Severe intra-abdominal infection in adults has also been associated with development of hyperbilirubinemia [2]. The vermiform appendix is important in surgical practice mostly due to its propensity for inflammation resulting in acute appendicitis. Worldwide acute appendicitis is the most common surgical emergency, affecting the abdomen. An emergency appendectomy is the most frequently performed abdominal operation and often it is the first major operative procedure done by a surgeon [3]. Overall lifetime risk of developing appendicitis is approximately $7 \%$ (8.6\% for males and $6.7 \%$ for females) $[4,5]$. The male: female ratio is $1.4: 1$ (range is $M: F=1: 1$ to 3:1) [5]. The incidence of acute appendicitis is decreasing steadily since late 1940 with present incidence rate approximately up to 110 (starting from 55.3 in females and 68.8 in males) cases per 10,0000 population per year [6].

Appendicitis commonly occurs in young adults (the highest incidence, approximately $40 \%$, in 2 nd decade of life i.e. $10-19$ years and $70 \%$ of the subjects are less than 30 years old.) [7, 8]. Acute appendicitis is relatively rare at the extreme of age $[9,10]$. Most subjects with acute appendicitis present with classic signs and symptoms for the ease of diagnosis. But in some atypical presentations diagnostic confusion and delay in treatment may occur. Crohn's disease, ectopic pregnancy, diverticulitis, endometriosis, mittleschmerz, mesenteric adenitis, omental torsion, pelvic inflammatory diseases, ruptured ovarian cyst, urinary tract infection may mimic acute appendicitis. Worldwide mean value for difference in diagnostic error rate, ranges from 12 to $23 \%$ and $24-42 \%$ respectively in men and women. Error occurs mostly in whites (74\%), while it is lesser in darker complexions (5\%) [9].

Surgical delay in a prompt management of the subjects with appendicitis (not with perforation, in particular), either due to delay in presentation (particularly in males with retrocaecal or retroileal position) or misjudgment, leads to dread complications like gangrenous changes and perforation of the appendix. Gangrene or perforation further leads to more complications like appendicular abscess formations, localized/generalized peritonitis, fecal fistula formation, intestinal obstruction due to adhesion formation, portal pyemia, sepsis and sterility in women of child-bearing age (though recent studies denies it as a major risk factor) with overall increased morbidity and prolonged hospital stay $[5,11]$. In adults, the incidence of appendicular perforation is 13-37\% [12]. The risk is higher in extreme of ages ( $45 \%$ in under
5 years age group and $51 \%$ in over 65 years age group) $[7,10]$. The mortality rate for uncomplicated, non-perforated appendicitis is $0.1-0.5 \%$ while that of perforated appendicitis is much higher, ranging from $3 \%$ overall to as high as $15 \%$ in elderly subjects [7]. On the contrary, in case of diagnostic difficulties and atypical presentations if appendectomy is performed based on clinical suspicion only, may increase the number of unnecessary appendectomies (up to 20\%) [13]. The rate of negative appendectomy (mostly due to pelvic inflammatory conditions) is 35 to $45 \%$ in women of child bearing age [14]. Unnecessary appendectomy caries a small risk of wound sepsis and the subsequent adhesive intestinal obstruction and occurrence of incisional hernia.

In spite of numerous advances in the diagnosis, evolved in the last 125 years, still now acute appendicitis continues to be a diagnostic challenge for surgeons and it remains mostly a clinical Diagnosis. Additional laboratory tests, scoring systems, Ultrasonography (sensitivity of 0.86 and specificity of 0.81 in experienced hand), Multi Detector computed tomography (MDCT, with sensitivity and specificity of 0.94 and 0.95 respectively), scintigraphy, Magnetic Resonance Imaging (specially in pregnancy) and diagnostic laparoscopy has been used which may support the primary clinical assessment to reach the diagnosis [15-18].

Several diagnostic scoring systems such as the Alvarado score (Scale 0-10), modified Alvarado score, Pediatric Appendicitis Score (PAS; scale 0-10), Rajalsteri Pengiran Anak Saleha Appendicitis (RIPASA) score for use in Asian patients (Scale 0-14), and Appendicitis Inflammatory Response Score (AIRS; scale 0-12) are commonly used in clinically suspected cases [16, 19-22]. But these scoring systems do not assess the risk of complications like appendicular gangrene or perforation. None of the above mentioned scores use hyperbilirubinemia as a marker. Some studies had showed that risk of appendicular perforation increases three times in subjects with total serum bilirubin levels more than $1 \mathrm{mg} / \mathrm{dl}$ [9].

Obstruction of appendix lumen, forming a closed loop, either by fecolith or mucosal edema is the major cause of pathological changes in acute appendicitis. Fecolith increases the severity of appendicitis, like $40 \%$ of uncomplicated, $65 \%$ of Gangrenous Appendicitis and 90\% of Perforative Appendicitis has been found to be associated with presence of fecolith [23, 24]. Appendix perforation occurs mostly distal to the point of luminal obstruction along the anti-mesenteric border. The appendix perforates about 12 to $48 \mathrm{~h}$ after the onset of acute appendicitis and is accompanied by an abscess cavity walled off by the small intestine and the omentum. Rarely free pertoration of the appendix into the peritoneal cavity occurs, which may be accompanied 
by peritonitis and septic shock and may be complicated by subsequent formation of multiple intraperitoneal abscesses.

Wangensteen, postulated that mucosal folds and a sphincter like orientation of the muscle Fibres at the appendiceal orifice makes the appendix susceptible to obstruction. He proposed sequence of events to explain appendicitis as depicted in Fig. 1 [9]. The flora of the inflamed appendix contains more bacterial load (anaerobes in $60 \%$ cases, peptostreptococcus, pseudomonas, bacteroides splanchnicus/intermedius, lactobacillus) than usual species in normal appendicitis [25]. Fusobacterium necrophorum /nucleatum, which is absent in normal situation, have been identified in $62 \%$ of inflamed appendices [26]. Bacteroides fragilis and Escherichia coli are the most frequently isolated bacteria in appendicitis [27]. Nearly $80 \%$ of blood supply to the liver comes from portal venous system, which carries absorbed substances including bacteria and toxins from intestine. Normally, small amount of bacteria and their toxic products get cleared after entering liver by detoxification and immunological action of reticulo-endothelial system. But

\section{CLOSED LOOP OBSTRUCTION is caused by inspissated stool (fecolith/appendicolith),lymphoid hyperplasia, undigested vegetable matter or seeds, parasites (Oxyuris vermicularis), scaring,Inflamatory Bowel Disease or a neoplasm ${ }^{[29]}$ and oedema of the mucosa and sub mucosa. \\ INTRA-LUMINAL DISTENTION and rise of intraluminal pressure as the appendix mucosa secretes fluid against the fixed obstruction. This luminal distention produces visceral pain experienced in the periumbilical area.}

INCREASED PRESSURE in the appendix wall exceeds the capillary pressure and creates mucosal ischemia \& ulceration with congestion of lymphoid tissue at base of the appendix.

\section{Luminal bacterial overgrowth and TRANSLOCATION of bacteria(common isolates being Bacteroides fragilis} and Escherichia coli) across the appendix wall.

Inflammed serosa contact parietal peritoneum. Inflammation of the adjacent peritoneum gives rise to the localized pain in the right lower quadrant ${ }^{[30]}$ Localized inflammatory process $\&$ a non-specific host immune response may progress to GANGRENE and necrosis leading to PERFORATION.

Trans-migration/translocation of bacteria, endo-toxins \& cytokines, either by direct invasion or through PORTAL VEIN. Escape of bacteria through perforation causes peritonitis.

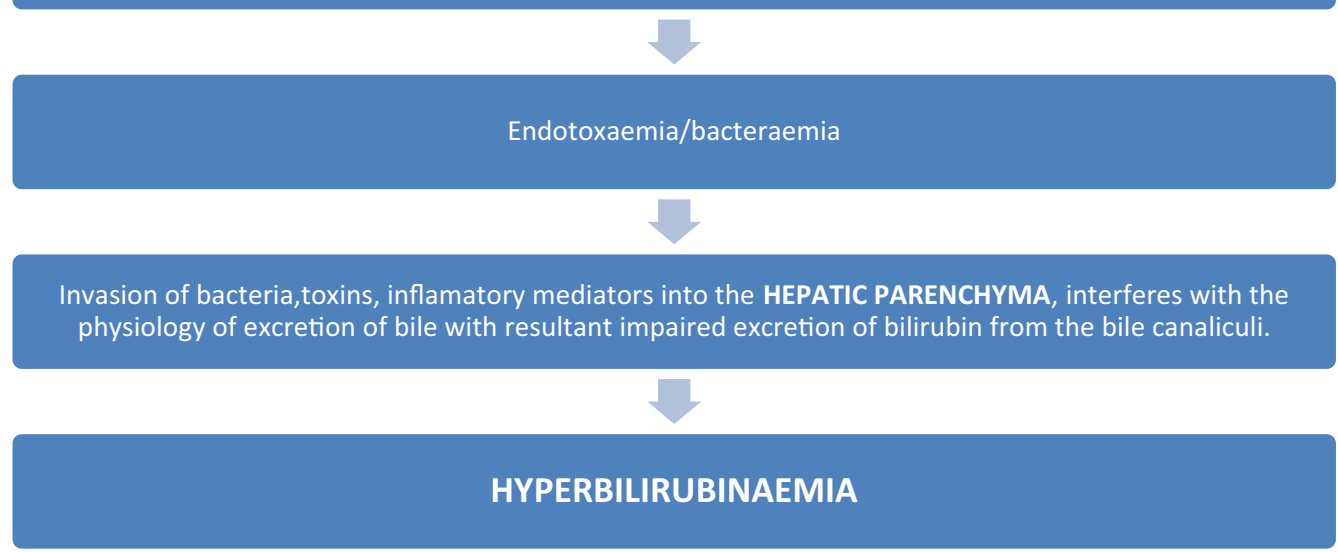

Fig. 1 Sequence of events in acute appendicitis giving rise to Hyperbilirubinemia 
kupffer cells may fail to clear the over abundant bacterial load in case of complicated acute appendicitis which in turn damage hepatocytes and rise serum bilirubin level. When there is bacteraemia, it leads to endotoxemia with resultant impaired excretion of bilirubin from the bile canaliculi [27]. Cytokines e.g. interleukin-6 (IL6), tumor necrosis factors (TNF) are also been considered to depress excretory functions of the liver resulting in hyperbilirubinemia without rise in liver enzymes level [28].

Aim of the present study is to evaluate the diagnostic role and predictive value of elevated total serum bilirubin level as a diagnostic parameter of complicated (gangrenous or perforated) appendicitis. Whether direct bilirubin, indirect bilirubin or both is increased in case of complicated appendicitis and their relation with complicated appendicitis were also studied. The relationship of other patient related parameters with complicated appendicitis were also evaluated in the present study.

\section{Methods}

This is an institution based (single center) prospective, observational study. The study population comprised of clinically suspected (110) subjects, satisfying the inclusion and exclusion criteria mentioned below. The primary data for this study were the investigation reports of the subjects.

\section{Inclusion criteria for the study group}

All cases of clinically diagnosed acute appendicitis of age 5 years and above, scheduled for appendectomy at emergency surgical unit of this hospital, were taken for this study.

\section{Exclusion criteria for the study group}

A. Subjects with age below 5 years.

B. Subjects with appendicular lump formation.

C. All subjects documented to have a past history of

1 Chronic liver disease with hyperbilirubinemia.

2 Chronic alcoholism (intake of alcohol of $>40 \mathrm{~g} /$ day for Men and $>20 \mathrm{~g} /$ day in Women for 10 years)

3 Hemolytic disease or Gilbert's Syndrome (conjugated hyperbilirubinemia with prevalence rate of 6\%), Dubin-Johnson syndrome.

4 Acquired or Congenital Biliary Disease.

D. Subjects with Acute hepatitis (viral/positive HbsAg and unknown).
E. Subjects with history of gastro intestinal malignancy.

F. History of hepatotoxic drug use either past or recent.

G. All subjects with cholelithiasis, benign recurrent intrahepatic cholestasis.

\section{Determination of reference value of serum bilirubin level in study population}

Serum bilirubin levels of healthy people (representing similar population with study participants) who were electively admitted with non gastrointestinal diseases (like benign skin lesions, fibroadenoma breast etc.) were checked. The mean value of their serum bilirubin level $(1.00 \mathrm{mg} / \mathrm{dl})$ was taken as normal reference value for the study population.

\section{Study procedure}

All participants in the study were clinically evaluated by detailed history and thorough clinical examination on initial contact. After clinical confirmation of acute appendicitis, the following investigations were done for all participants:

1. Routine blood investigations (i.e. complete blood count, platelet count etc.).

2. Peripheral blood smear to rule out hemolytic anemia.

3. Serum Bilirubin (Total and Direct bilirubin).

4. Liver Enzymes, which include-ALT (Alanine transaminase), AST (Aspartate transaminase), ALP (Alkaline phosphatase).

5. Seropositivity for HbsAg, HIV, HCV.

6. Serum CRP Level.

7. Fasting blood sugar, renal function test.

8. ECG, digital chest X-ray-PA view and USG Scan of whole abdomen (specially to assess the appendix diameter, peri appendicular collection and presence of fecolith).

Blood samples were drawn within half an hour of presentation in the hospital and radiological investigations were done within $2 \mathrm{~h}$ of admission. All the available data were recorded. After initial stabilization, these subjects were operated (emergency open appendectomy). Finally, clinical diagnosis was confirmed by post operative histopathological examination. Histopathological examination was considered final in diagnosing and categorizing subjects as.

(1) Negative for the study (having normal appendix or acute uncomplicated appendicitis)

(2) Positive for the study (Acute Appendicitis with perforation/gangrene). 
The post-operative follow up was done for a period of 5 days in hospital and at least one more Out-Patients Department visit on 7th Post operative day. The serum bilirubin level was rechecked on 7th post-operative day, during follow-up in OPD. Their clinical data were compiled and analyzed.

\section{Accepted standard normal ranges for this study were like the following}

Serum Bilirubin: Total $=0.3-1.0 \mathrm{mg} / \mathrm{dl}$, Direct Bilirubin $=0.1-0.3 \mathrm{mg} / \mathrm{dl}$.

Liver Enzymes: ALT $=0-40 \mathrm{U} / \mathrm{l}, \mathrm{AST}=0-40 \mathrm{U} / \mathrm{l}$, $\mathrm{ALP}=30-130 \mathrm{U} / \mathrm{l}$.

The statistical analysis was carried out using available standard statistical software (SPSS 23). All statistical tests was one tailed and $p$ value $<0.05$ was taken as significant.

\section{Results}

Total number of cases was 110, all completed the follow up. Systematic analysis of all collected data revealed the following

A. Baseline characteristics: Incidence of complicated appendicitis among subjects undergoing appendectomy was found as following

\section{(I)Gender specific}

Out of total 110 subjects of acute appendicitis, enrolled for the study, 66 subjects (60\%) were male while the remaining 44 subjects $(40 \%)$ were female. So, male:female ratio was 1.5:1. Overall occurrence of complicated (gangrenous/perforated on the basis of intra operative as well as histopathology report) appendicitis was $31.8 \%$ (35 out of them 15 were males and 20 females) and $68.2 \%$ (75 out of them 51 were males and 24 were females) subjects had appendicitis without complications. Complicated appendicitis was more (57.2\%) in females than males $(42.8 \%)$. But $45.45 \%$ of all females had complicated appendicitis while among males the rate of complication was $22.72 \%$. $44 \%$ males and $25 \%$ females had simple appendicitis while $12 \%$ male and $8 \%$ females had gangrenous appendicitis. Perforated appendicitis was found in $4 \%$ males and $7 \%$ females (Table 1 ).

\section{(II) Age specific}

The overall mean age of all 110 subjects was $23.5 \pm 13.5$ years (range $5-62$ years). The mean age for males was $24.34 \pm 12.70$ years (range $5-60$ years) and the mean age for females was $22.29 \pm 14.84$ years (range 6-62 years). Majority (almost $83 \%$ ) of the cases belongs to first two decades (5-19 years) of life. But occurrence rate of complicated appendicitis was more at the extremes of ages. The ratio of complicated appendicitis among all study population were $43.75 \%$ (in $<10$ years age group), $70.96 \%$ (in $10-19$ years age group), $25 \%$ (in $50-59$ years age) and 33\% (in age group more than 60 years) (Table 1 ).

B. Relationship of direct bilirubin and indirect bilirubin with complicated appendicitis

Out of 110 subjects of acute appendicitis 41 subjects (37.27\%) had hyperbilirubinemia (raised serum total bilirubin level $>1 \mathrm{mg} / \mathrm{dl}$ ). Out of 35 subjects diagnosed as complicated appendicitis 32 subjects $(91.42 \%)$ had raised total bilirubin levels $(>1.0 \mathrm{mg} / \mathrm{dl})$. While the remaining 03 subjects $(8.58 \%)$ had normal levels $(<1.0 \mathrm{mg} / \mathrm{dl})$. Among 75 subjects diagnosed as acute simple appendicitis 09 subjects $(12 \%)$ had raised total bilirubin level $(>1.0 \mathrm{mg} / \mathrm{dl})$, while the remaining 66 subjects $(88 \%)$ had normal levels $(<1.0 \mathrm{mg} / \mathrm{dl})$.

The mean Total Bilirubin Level for all subjects with acute uncomplicated appendicitis was $0.79 \pm 0.16 \mathrm{mg} / \mathrm{dl}$ (range being $0.45-1.20 \mathrm{mg} / \mathrm{dl}$ ) and that for complicated appendicitis was $1.39 \pm 0.26 \mathrm{mg} / \mathrm{dl}$ (range being 0.68 $2.20 \mathrm{mg} / \mathrm{dl}$ ) value was statistically significant $p<0.05$. Hence, it was seen that subjects with complicated (perforated/gangrenous) appendicitis had higher level of total bilirubin as compared to that of uncomplicated acute appendicitis (Table 2).

The mean DIRECT BILIRUBIN for uncomplicated appendicitis subjects was $0.43 \pm 0.10 \mathrm{mg} / \mathrm{dl}$ (range being $0.20-0.70 \mathrm{mg} / \mathrm{dl}$ ) and that for complicated appendicitis was $0.72 \pm 0.13 \mathrm{mg} / \mathrm{dl}$ (range being $0.38-1.10 \mathrm{mg} / \mathrm{dl}$ ), which was statistically significant $(p<0.05)$ rise of direct bilirubin with occurrence of complicated appendicitis. The mean Indirect Bilirubin for subjects with uncomplicated appendicitis was $0.36 \pm 0.08 \mathrm{mg} / \mathrm{dl}$ (range being $0.16-0.60 \mathrm{mg} / \mathrm{dl}$ ) and that for complicated appendicitis was $0.66 \pm 0.14 \mathrm{mg} / \mathrm{dl}$ (range being $0.30-1.10 \mathrm{mg} / \mathrm{dl}$ ), which was statistically significant $(p<0.05)$ rise of direct bilirubin with occurrence of complicated appendicitis.

There was significant rise in both components of total bilirubin, direct as well as indirect bilirubin in subjects with complicated appendicitis, so it was Mixed Type of Hyperbilirubinemia in gangrenous/perforated appendicitis. The sensitivity of Total serum bilirubin in predicting complicated appendicitis was found 91.43\% (76.942\% to $98.196 \%)$, where as the specificity of this test was $88.00 \%$ ( $78.439 \%$ to $94.363 \%)$. positive predictive value and negative predictive value were $78.03 \%$ and $95.65 \%$ respectively. Positive likelihood ratio and negative likelihood ratio were found to be 7.619 and 0.097 respectively 


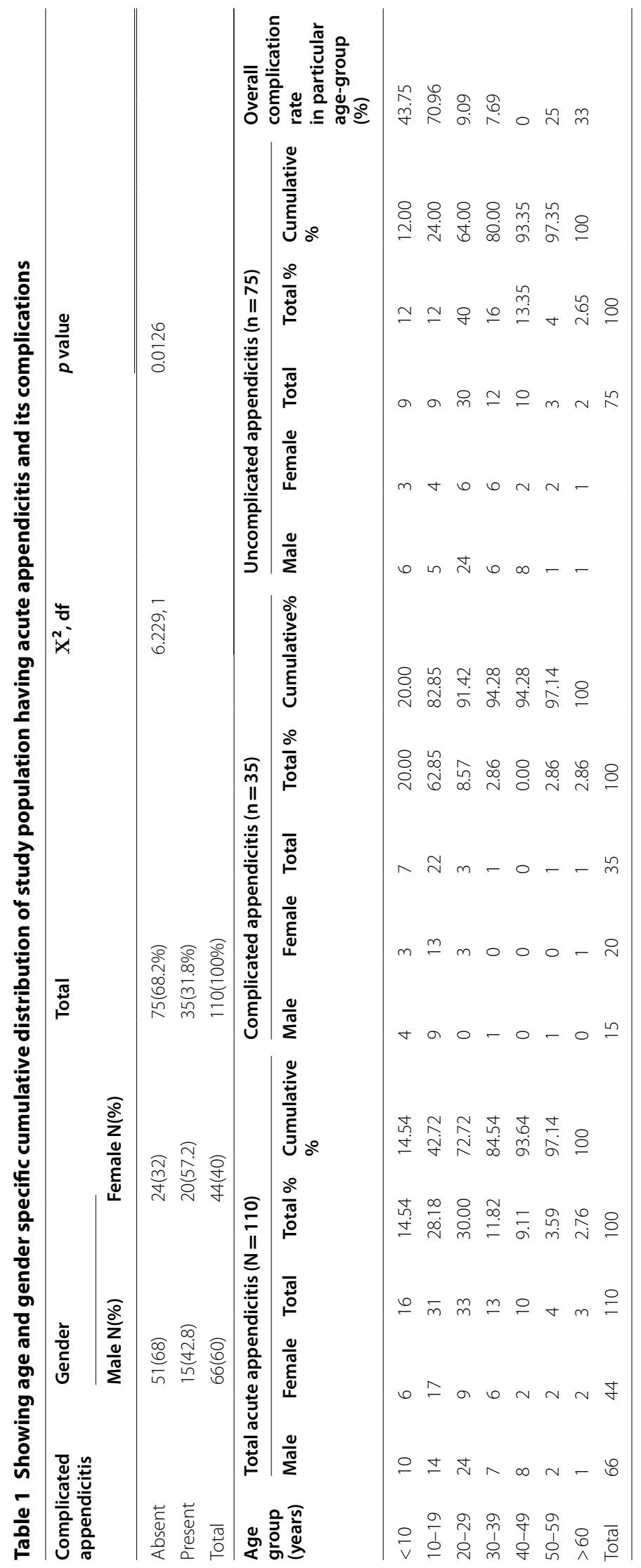




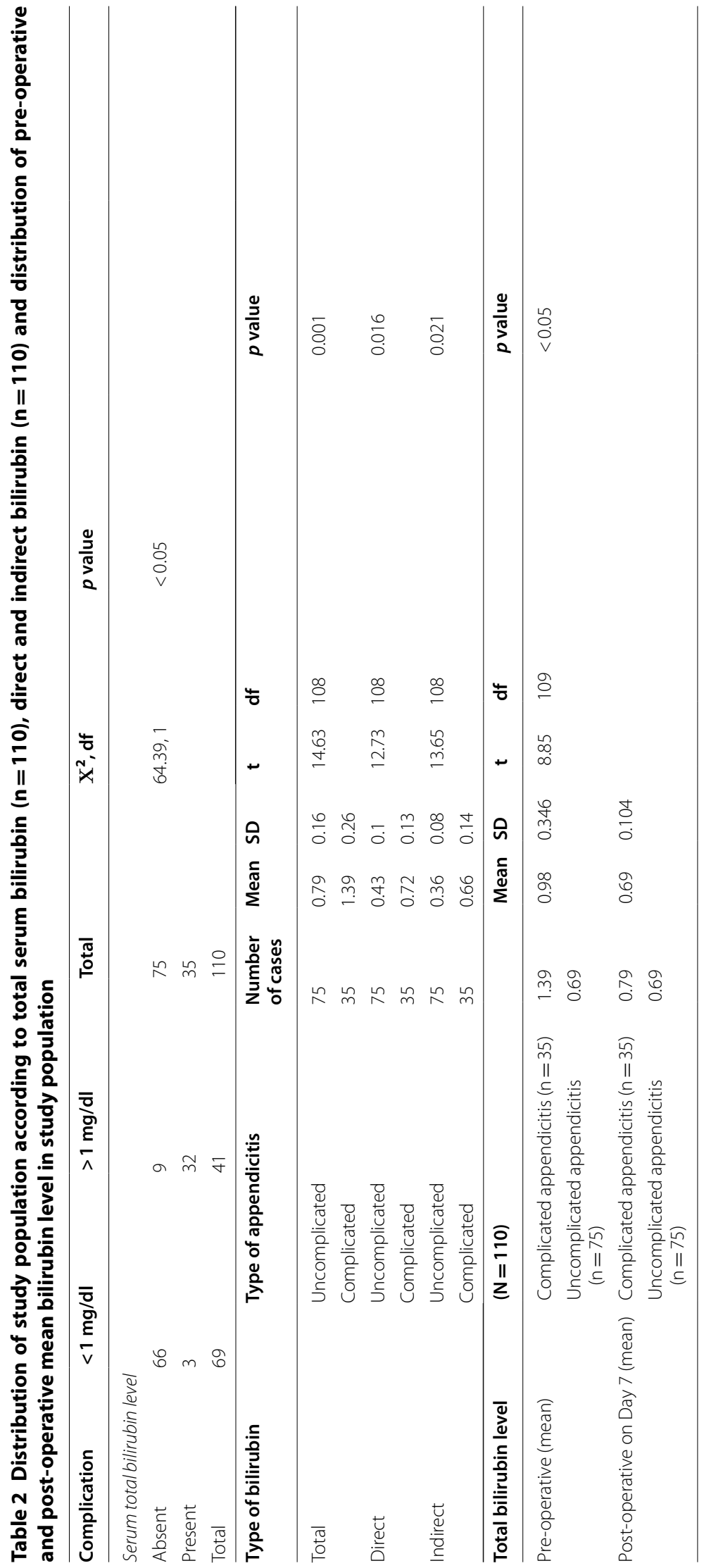


taking prevalence of Complicated appendicitis be $31.80 \%$ (Table 2).

After plotting the True Positive Rate (TPR)/sensitivity of Total Serum Bilirubin level against the False Positive Rate (FPR) of its detection of complicated appendicitis at various threshold settings a ROC (Receiver Operating Characteristic) curve was obtained which shows optimal criterion at Total Bilirubin Level $1.06 \mathrm{mg} / \mathrm{dl}$ where sensitivity was $91.43 \%$ and specificity was $97.33 \%$ at $95 \%$ confidence interval with $31.8 \%$ disease prevalence (Table 2).

The prevalence of complicated appendicitis was found to be $31.8 \%$ among all cases. So Area under the ROC curve (AUC) was 0.958 [standard error 0.0246, 95\% Confidence interval0.902 to 0.987 , z statistic 18.614 , Significance level $p($ area $=0.5)<0.0001]$. Figure 2 shows criterion values and coordinates of the ROC curve. This ROC (Receiver operating characteristic) curve reveals diagnostic ability of Total Serum Biliruin level for complicated appendicitis, after taking into consideration of prevalence of complicated appendicitis among total cases. Optimal criterion was found at total bilirubin level $1.06 \mathrm{mg} / \mathrm{dl}$.

So we can infer that, subjects with clinical features suggestive of appendicitis with higher values of serum total bilirubin, are more susceptible of having complicated appendicitis than those with normal or mildly elevated total bilirubin level.

\section{Comparison of pre-operative and post-operative day 7 total bilirubin level}

Serum total bilirubin level was checked in all study subjects irrespective of their final diagnosis on 7th Postoperative day to confirm that the hyperbilirubinemia was due to complicated appendicitis and it comes to normal range after appendectomy. It was seen that mean total bilirubin level was $1.39 \mathrm{mg} / \mathrm{dl}$ in complicated appendicitis group $(\mathrm{n}=35)$ and $0.79 \mathrm{mg} / \mathrm{dl}$ in uncomplicated appendicitis group. Both the group showed mean serum total bilirubin value $0.69 \mathrm{mg} / \mathrm{dl}$ on 7 th postoperative day. The preoperative mean total bilirubin of all the study subjects was $0.9841 \mathrm{mg}$ which came to a mean value of $0.6885 \mathrm{mg} / \mathrm{dl}$ which was statistically significant $(p<0.05)$ (Table 2).

3 Relationship of other patient related parameters with complicated appendicitis

\section{Alvarado score}

The mean value for ALVARADO SCORE in Acute uncomplicated Appendicitis was $7.25 \pm 0.71$ (range

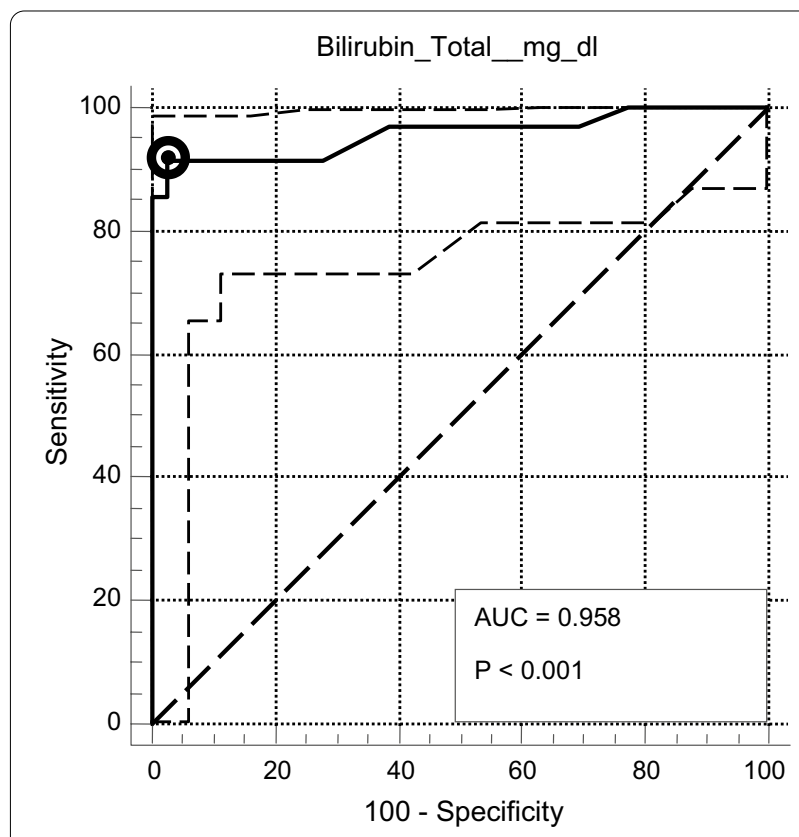

Fig. 2 statistical significance of hyperbilirubinemia in complicated appendicitis with criterion values and coordinates of the roc curve $(n=110)$

6-9) whereas for complicated appendicitis it is $8.5 \pm 0.77 \mathrm{U} / \mathrm{l}$ (range $7-10 p$ value $>0.05$ ) which is statistically significant. Only $5.33 \%$ subjects without complicated appendicitis had Mantrels Score more than mean value for complicated appendicitis cases. So it was concluded that MANTRELS SCORE were significantly high in appendicular gangrenous change/perforation cases, pre-operatively. And only $23 \%$ of all subjects with perforations $(n=13)$ had SCORE below that mean value for complication at presentation. Score above mean value 7.66 had a sensitivity of $94.28 \%$ and specificity of $70.66 \%$ for complications (Table 3 ). Area Under Curve was 0.825 (range 0.741 to 0.891 ), Positive Likelihood Ratio $=3.214$ Negative Likelihood Ratio $=0.081$, Positive Predictive Value $=59.980 \%$ and Negative Predictive Value $=96.367 \%$ at $31.800 \%$ complicated appendicitis disease prevalence.

\section{Duration of pain}

This study revealed relationship between mean duration of pain and complicated appendicitis among the study population. The mean duration of pain was shorter for subjects with an acute uncomplicated appendicitis $(9.0 \mathrm{~h} \pm 5.12$ range 6-12 $\mathrm{h}$ ) compared to those with a gangrenous/perforated appendix $(20.2 \pm 1.49 \mathrm{~h}$, range $14-36 \mathrm{~h})$, it reached statistical significance $(p<0.05)$. The scattered plot diagram shows linear regression 


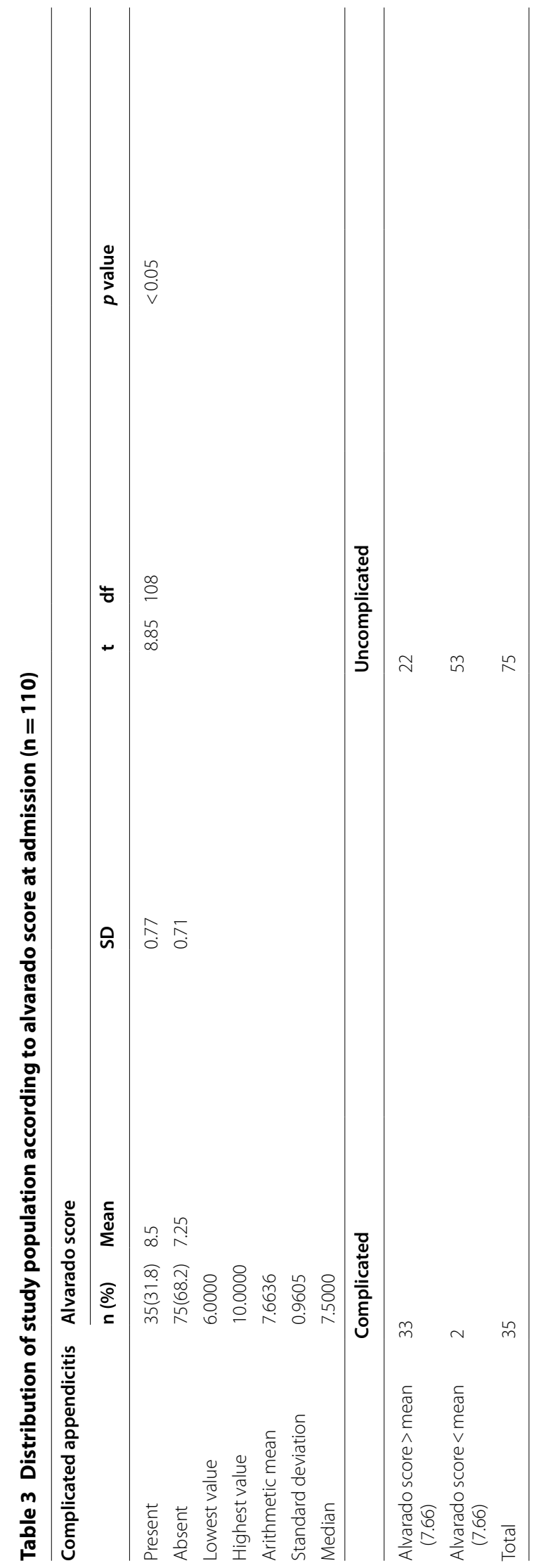


relationship between rise of total bilirubin level $(0.0396$ times) with increase of duration of pain (each hour) (Fig. 3).

\section{Gender wise distribution of pain duration}

This study showed among 66 men mean duration of pain was $11.78 \mathrm{~h} \pm 6.1$ (range $6-36 \mathrm{~h}$ ) while it is $13.75 \mathrm{~h} \pm 5.9$ (range 6-30 h) among 44 females (Fig. 3).

\section{Temparature}

$40 \%$ of subjects with acute uncomplicated appendicitis and $71.42 \%$ of subjects with a gangrenous/perforated appendicitis presented with a fever. Statistical analysis revealed significant difference between two groups. And $p$ value was $<0.05$. The mean temperature in acute uncomplicated appendicitis was $98.02+1.30{ }^{\circ} \mathrm{F}$ (range 97-100 ${ }^{\circ} \mathrm{F}$ ) whereas for complicated appendicitis it is $99 \pm 1.49^{\circ} \mathrm{F}$ (range $97-101^{\circ} \mathrm{F}$ ). Rise of temperature above mean value had sensitivity $71.43 \%$ (53.69\% to $85.36 \%$ ), specificity $60 \%$ (48.04\% to $71.15 \%$ ), Positive Likelihood
Ratio of 1.78 and Negative Likelihood Ratio of 0.476 (Table 4).

4. Relationship between liver enzymes-alkaline phosphatage (ALP), aspartate amino transferase (AST), alanine amino transferase (ALT) and c reactive protein (CRP) level. with complicated appendicitis:

The mean value for ALP in acute uncomplicated appendicitis was $126.04 \pm 7.42 \mathrm{U} / \mathrm{l}$ (range 112$158 \mathrm{U} / \mathrm{l})$ whereas for complicated appendicitis it was $125.85 \pm 5.01 \mathrm{U} / \mathrm{l}$ (range 120-146 U/l $p$ value $>0.05$ ) which is not statistically significant. So it was concluded that ALP cannot differentiate between uncomplicated appendicitis and appendicular gangrenous change/perforation pre-operatively. And only $22.7 \%$ of all subjects $(n=110)$ had MILDLY elevated serum ALP level at presentation.

The mean value for AST in acute uncomplicated appendicitis was $33.70 \pm 2.99 \mathrm{U} / \mathrm{l}$ (range 26-39 U/l) whereas for complicated appendicitis it was $32.88 \pm 3.38 \mathrm{U} / \mathrm{l}$ (range $26-39 \mathrm{U} / 1 p$ value $>0.05$ ) which
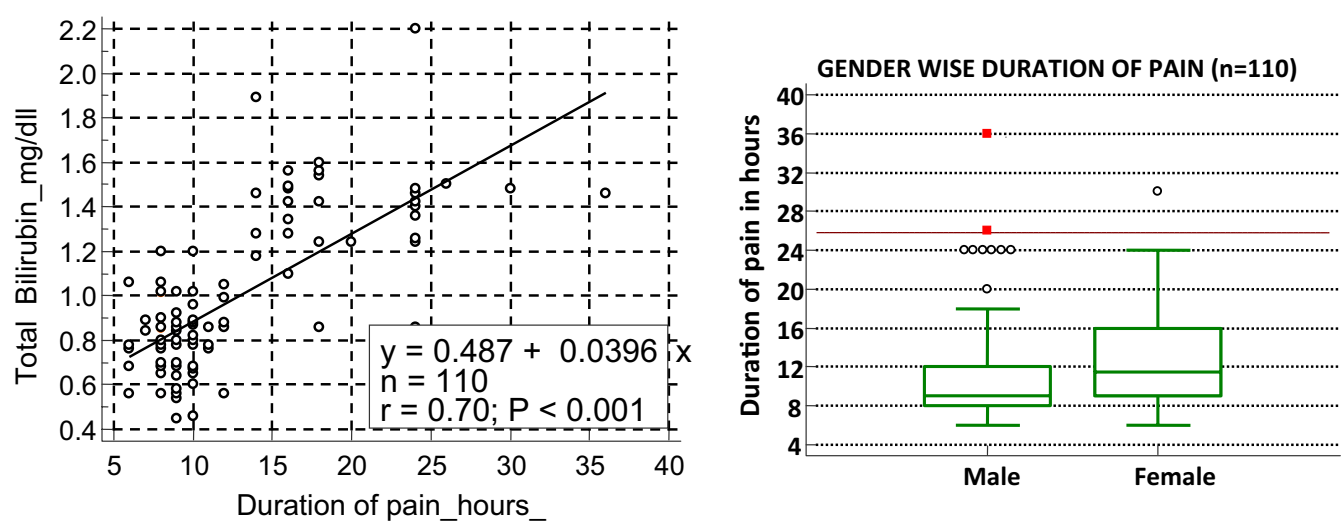

Fig. 3 linear regression analysis of relationship between pain duration and total bilirubin and gender wise duration of pain $(\mathrm{n}=110)$

Table 4 Distribution of study population according to axillary temparature at admission $(\mathbf{n}=110)$

\begin{tabular}{|c|c|c|c|c|c|}
\hline \multirow[t]{2}{*}{ Complicated appendicitis } & \multicolumn{2}{|c|}{ Temparature } & \multirow[t]{2}{*}{ Total } & \multirow[t]{2}{*}{$\mathrm{X}^{2}, \mathrm{df}$} & \multirow[t]{2}{*}{$p$ value } \\
\hline & $<98^{\circ} \mathrm{F}$ & $>98^{\circ} \mathrm{F}$ & & & \\
\hline Absent & 45 & 30 & 75 & $9.343,1$ & $<0.05$ \\
\hline Present & 10 & 25 & 35 & & \\
\hline Total & 55 & 55 & 110 & & \\
\hline Lowest value & & & 97.0000 & & \\
\hline Highest value & & & 101.0000 & & \\
\hline Arithmetic mean & & & 98.3364 & & \\
\hline $95 \% \mathrm{Cl}$ for the arithmetic mean & & & 98.0651 to 98.6076 & & \\
\hline Median & & & 98.0000 & & \\
\hline
\end{tabular}


is not statistically significant. So it was concluded that AST cannot differentiate between uncomplicated appendicitis and appendicular gangrenous change/ perforation pre-operatively. None $(0 \%)$ of all subjects $(n=110)$ had elevated serum AST level at presentation.

The mean value for ALT in acute uncomplicated appendicitis was $33.34 \pm 2.71 \mathrm{U} / \mathrm{l}$ (range 27-40 U/l) whereas for complicated appendicitis it was $32.77 \pm 2.75 \mathrm{U} / 1$ (range $28-38 \mathrm{U} / 1 p$ value $>0.05$ ) which is not statistically significant. So it was concluded that ALT cannot differentiate between uncomplicated appendicitis and appendicular gangrenous change/perforation pre-operatively. And only $0.9 \%$ of all subjects $(n=110)$ had elevated serum ALT level at presentation.

So, this study showed isolated hyperbilirubinemia without much elevation in the liver enzymes. This isolated occurrence of hyperbilirubinemia was a significant predictor of gangrenous/perforated appendicitis.

90.7\% of all uncomplicated Appendicitis had normal CRP level $(<0.6 \mathrm{mg} / \mathrm{dl})$ whereas only $14 \%$ of complicated appendicitis subjects had normal CRP level. Rest $86 \%$ of complicated appendicitis subjects had statistically significant rise of CRP $(>0.6 \mathrm{mg} / \mathrm{dl})$ which was raised only 9.3\% of uncomplicated appendicitis cases. So it was concluded that raised CRP level can differentiate between uncomplicated appendicitis and appendicular gangrenous change/perforation pre-operatively (Table 5).

5. Ultra sonographical findings of appendix:

1 Appendix outer diameter on USG scan: The mean outer diameter of appendix of all study population was $7.6 \mathrm{~mm}$. The mean appendix diameter on USG in uncomplicated Appendicitis was $6.64 \mathrm{~mm} \pm 0.69$ (range 6-8 $\mathrm{mm}$ ) whereas for complicated appendicitis it was $9.71 \mathrm{~mm} \pm 1.27$ (range 7-12 $\mathrm{mm}, p$ value $>0.05$ ) which was statistically significant. Sensitivity and specificity of increased appendix diameter on USG got sensitivity of $94.28 \%$ and specificity of $52.0 \%$, Positive Likelihood Ratio 1.964, Negative Likelihood Ratio 0.110, Positive Predictive Value 47.805\% and Negative Predictive Value 95.126\% (Table 6). Scattered plot diagram showed one unit increase in appendix diameter was associated with 3.6\% increase of total bilirubin level (Fig. 4). So it was concluded that increased appendix diameter on USG was associated with appendicular gangrenous change/perforation pre-operatively.

2 93.3\% of all uncomplicated Appendicitis had clear appendix lumen on USG whereas only 11.4\%

Table 5 Distribution of study population according to serum ALT, AST, ALP, CRP level at admission $(\mathbf{n}=110)$

\begin{tabular}{|c|c|c|c|c|c|c|c|c|}
\hline \multicolumn{2}{|c|}{ Complicated appendicitis } & \multicolumn{3}{|l|}{ ALT } & & \multirow[t]{2}{*}{ Total } & $\mathrm{X}^{2}, \mathrm{df}$ & \multirow[t]{2}{*}{$p$ value } \\
\hline & & $<40$ & & $>40$ & & & & \\
\hline \multicolumn{2}{|l|}{ Absent } & 74 & & 1 & & 75 & $0.471,1$ & $>0.05$ \\
\hline \multicolumn{2}{|l|}{ Present } & 35 & & 0 & & 35 & & \\
\hline \multicolumn{2}{|l|}{ Total } & 109 & & 1 & & 110 & & \\
\hline \multirow{2}{*}{\multicolumn{2}{|c|}{ Complicated appendicitis }} & \multicolumn{3}{|l|}{ AST } & & \multirow[t]{2}{*}{ Total } & $\mathrm{X}^{2}, \mathrm{df}$ & \multirow[t]{2}{*}{$p$ value } \\
\hline & & $<40$ & & $>40$ & & & & \\
\hline \multicolumn{2}{|l|}{ Absent } & \multicolumn{2}{|l|}{75} & \multicolumn{2}{|c|}{0} & 75 & $14.545,1$ & \multirow[t]{3}{*}{$>0.05$} \\
\hline \multicolumn{2}{|l|}{ Present } & \multicolumn{2}{|l|}{35} & \multicolumn{2}{|c|}{0} & \multicolumn{2}{|l|}{35} & \\
\hline \multicolumn{2}{|l|}{ Total } & \multicolumn{2}{|l|}{110} & \multicolumn{2}{|c|}{0} & \multicolumn{2}{|l|}{110} & \\
\hline \multirow{2}{*}{\multicolumn{2}{|c|}{ Complicated appendicitis }} & \multicolumn{3}{|l|}{ ALP } & & \multirow[t]{2}{*}{ Total } & $\mathrm{X}^{2}, \mathrm{df}$ & \multirow[t]{2}{*}{$p$ value } \\
\hline & & \multicolumn{2}{|l|}{$<130 \mathrm{n}(\%)$} & \multicolumn{2}{|l|}{$>130 \mathrm{n}(\%)$} & & & \\
\hline \multicolumn{2}{|l|}{ Absent } & \multicolumn{2}{|l|}{$57(76)$} & 18(24) & & 75 & $0.217,1$ & $>0.05$ \\
\hline Present & & $28(80)$ & & 7(20) & & 35 & & \\
\hline Total & & $85(77.3)$ & & $25(22.7)$ & & & & \\
\hline Complicated & CRP & & & & Total & & $p$ value & \\
\hline & $<0$. & $n(\%)$ & $>0.6 \mathrm{n}(\%)$ & & & & & \\
\hline Absent & $68(9$ & & $7(9.3)$ & & 75 & & $p<0.05$ & \\
\hline Present & $5(14$ & & $30(86)$ & & 35 & & $X^{2}=61.802$ & \\
\hline Total & 73 & & 37 & & 110 & & $\mathrm{Df}=1$ & \\
\hline
\end{tabular}


Table 6 Distribution of study population according to mean appendix diameter, peri-appendix collection and presence of fecolith on USG $(n=110)$

\begin{tabular}{|c|c|c|c|c|c|c|}
\hline \multirow{2}{*}{$\begin{array}{l}\text { Complicated } \\
\text { appendicitis }\end{array}$} & \multicolumn{6}{|c|}{ Mean appendix outer diameter on USG in two groups } \\
\hline & $\mathrm{n}(\%)$ & Mean diameter $(\mathrm{mm})$ & SD & $\mathrm{X}^{2}$ & df & $p$ value \\
\hline Abesent & $75(68.2)$ & 6.64 & 0.69 & 21.66 & 1 & $<0.05$ \\
\hline \multirow[t]{3}{*}{ Present } & $35(31.8)$ & 9.71 & 1.27 & & & \\
\hline & \multicolumn{6}{|c|}{ Distribution according to appendix diameter $\mathrm{n}(\%)$} \\
\hline & $<7.6 \mathrm{~mm}$ & $>7.6 \mathrm{~mm}$ & Total & $\mathrm{X}^{2}$ & df & $p$ value \\
\hline Abesent & 33(94.29) & $36(48)$ & 69 & 21.66 & 1 & $<0.05$ \\
\hline Present & $2(5.71)$ & $39(52)$ & 41 & & & \\
\hline \multirow[t]{3}{*}{ Total } & $35(31.8)$ & $75(68.2)$ & 110 & & & \\
\hline & \multicolumn{6}{|c|}{ Peri-appendix collection } \\
\hline & Present n(\%) & Absent $n(\%)$ & Total & $\mathrm{X}^{2}$ & df & $p$ value \\
\hline Absent & $0(0)$ & $75(100)$ & 75 & 76.67 & 1 & $<0.05$ \\
\hline Present & $27(77.1)$ & $8(22.9)$ & 35 & & & \\
\hline \multirow[t]{3}{*}{ Total } & $27(24.5)$ & $83(75.5)$ & 110 & & & \\
\hline & \multicolumn{6}{|c|}{ Appendix lumen obstruction by fecolith $\mathrm{n}(\%)$} \\
\hline & Present n(\%) & Absent n(\%) & Total & $\mathrm{X}^{2}$ & df & $p$ value \\
\hline Absent & $5(6.7)$ & 70(93.3) & 75 & 70.05 & 1 & $<0.05$ \\
\hline Present & $31(88.6)$ & $4(11.4)$ & 35 & & & \\
\hline Total & $36(32.72)$ & $74(67.28)$ & 110 & & & \\
\hline
\end{tabular}

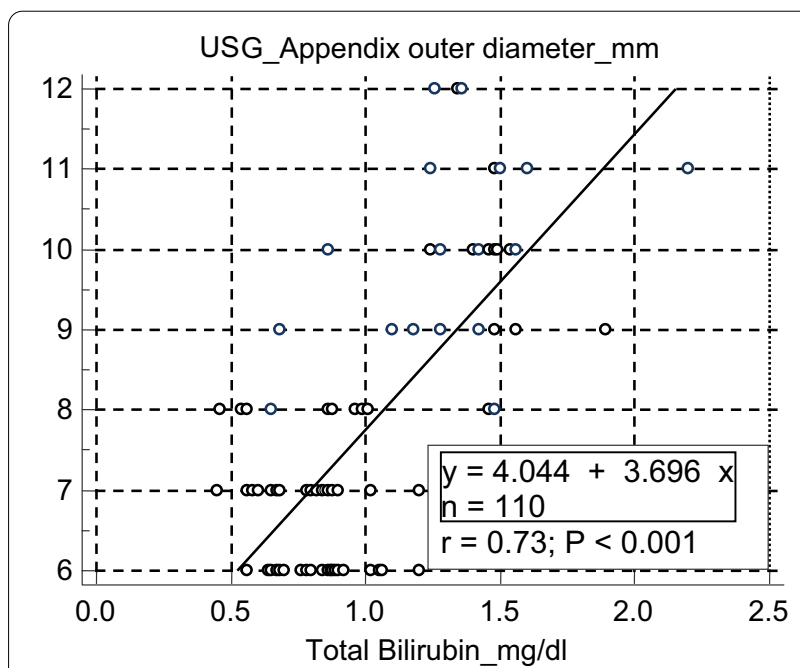

Fig. 4 scattered plot diagram showing relationship between increase in appendix diameter with increase in serum total bilirubin level

of complicated appendicitis subjects had clear lumen. Rest $88.6 \%$ of complicated appendicitis subjects had appendix lumen obstruction by fecolith, evident on pre-operative USG. But only $6.7 \%$ of uncomplicated appendicitis cases had luminal obstruction. So it was concluded that luminal obstruction on USG can predict appendicular gangrenous change/perforation pre-operatively (Table 6).

3 Statistically significant $(p<0.05)$ difference was found while assessing the cases, preoperatively on USG, for peri-appendix collection. No subjects with uncomplicated appendicitis $(n=75)$ had any peri-appendix fluid collection. But among subjects with complicated appendicitis, $77.1 \%$ had pri-appendix fluid collection and only $22.9 \%$ had no collection as was evident on USG scan.

6. Multivariate regression analysis of different parameters with occurrence of hyperbilirubinemia:

Analysis of relationship of different patient related factors with occurrence of hyperbilirubinemia was done in this study (Table 7). According to the analysis non significant variables with occurrence of hyperbilirubinemia are-Age $<19$ years $=1.236(0.264-5.790)$, Gender-Female $=0.462 \quad(0.124-1.714)$, duration of pain $<9 \mathrm{~h}=0.955$, Liver enzymes (viz. ALP, AST, ALT), $\mathrm{C}$ reactive Protein $<0.6=1.783$, Appendix outer diameter $<8 \mathrm{~mm}=1.620$. The significant variable was complicated appendicitis $=0.01(0.001-0.114)$. 
Table 7 Multivariate regression analysis of different parameters with occurrence of complicated appendicitis

\begin{tabular}{|c|c|c|c|c|c|}
\hline \multirow{2}{*}{$\begin{array}{l}\text { Parameters in relation to development of complicated } \\
\text { appendicitis absent }=1 \text {, present }=2(1)\end{array}$} & \multirow[t]{2}{*}{ df } & \multirow[t]{2}{*}{ Significance $(p)$} & \multirow[t]{2}{*}{$\operatorname{Exp}(B)$} & \multicolumn{2}{|c|}{$95 \% \mathrm{Cl}$ for $\operatorname{Exp}(\mathrm{B})$} \\
\hline & & & & Lower & Upper \\
\hline Duration of pain & 1 & 0.957 & 0.955 & 0.177 & 5.157 \\
\hline CRP: $<0.6=1>0.6=2(1)$ & 1 & 0.547 & 1.783 & 0.272 & 11.705 \\
\hline Appendix: $<7.6 \mathrm{~mm}=1>7.6 \mathrm{~mm}=2(1)$ & 1 & 0.689 & 1.620 & 0.153 & 17.110 \\
\hline Hyperbilirubinemia & 1 & 0.000 & 0.010 & 0.001 & 0.114 \\
\hline Constant & 1 & 1.000 & 0.000 & & \\
\hline
\end{tabular}

\section{Discussion}

Emergency appendectomy for uncomplicated acute appendicitis usually follows a short recovery period but same for the gangrenous or perforated appendicitis may be a life threatening one. To avoid morbidities prompt diagnosis is the key factor. Estimation of serum total bilirubin level is not commonly done as a marker of complicated appendicitis in an emergency setting. However, several previous studies have shown hyperbilirubinemia has high specificity for appendicular perforation. Comparison of sensitivity, specificity, PPV, NPV of serum total bilirubin in various studies including the present one has been depicted in Table 8. In adults, hyperbilirubinemia is commonly seen in liver or gallbladder diseases. Gilbert's syndrome may also cause isolated indirect hyperbilirubinemia but its prevalence is 6\% [38]. This prevalence is found considerably less than the incidence of Hyperbilirubinemia associated with acute appendicitis (evidenced both in previous studies as well as present study). The data was documented at the time of admission, so hyperbilirubinemia as a consequence of liver injury due to anesthetic agents, blood transfusion, or

Table 8 Comparison of sensitivity, specificity, ppv, $\mathrm{npv}$ of serum total bilirubin in various studies

\begin{tabular}{|c|c|c|c|c|c|c|c|c|c|}
\hline Authors & Study type & $\begin{array}{l}\text { Number } \\
\text { of subjects }\end{array}$ & $\begin{array}{l}\text { Age (years, } \\
\text { mean, range) }\end{array}$ & $\begin{array}{l}\text { Hystologically } \\
\text { confirmed } \\
\text { appendicitis } \\
\text { (n) }\end{array}$ & $\begin{array}{l}\text { Perforated } \\
\text { appendix } \\
\text { (n) }\end{array}$ & Sensitivity & Specificity & $\begin{array}{l}\text { Positive } \\
\text { likelihood } \\
\text { ratio }\end{array}$ & $\begin{array}{l}\text { Negative } \\
\text { likelihood } \\
\text { ratio }\end{array}$ \\
\hline $\begin{array}{l}\text { Present } \\
\text { Study by } \\
\text { Bakshi et al. } \\
2019\end{array}$ & $\begin{array}{l}\text { Prospective } \\
\text { non-rand- } \\
\text { omized }\end{array}$ & 110 & $\begin{array}{c}23.5 \text { years } \\
(5-62)\end{array}$ & 110 & 35 & 0.9143 & 0.88 & 7.619 & 0.097 \\
\hline $\begin{array}{l}\text { Estrada et al. } \\
\text { [7] }\end{array}$ & $\begin{array}{l}\text { Retrospective } \\
\text { non-rand- } \\
\text { omized }\end{array}$ & 170 & $\begin{array}{r}33 \text { years } \\
(5-66)\end{array}$ & 157 & 41 & 0.56 & 0.69 & 1.81 & 0.64 \\
\hline $\begin{array}{r}\text { Emmanuel } \\
\text { et al. [31] }\end{array}$ & $\begin{array}{l}\text { Retrospective } \\
\text { non-rand- } \\
\text { omized }\end{array}$ & 472 & $\begin{array}{r}27 \text { years } \\
(5-82)\end{array}$ & 386 & 45 & 0.60 & 0.70 & 1.99 & 0.57 \\
\hline Khan et al. [32] & $\begin{array}{l}\text { Prospective } \\
\text { non-rand- } \\
\text { omized }\end{array}$ & 122 & $\begin{array}{r}29 \text { years } \\
(8-73)\end{array}$ & 118 & 18 & 0.72 & 0.18 & 0.88 & 1.54 \\
\hline Sand et al. [33] & $\begin{array}{l}\text { Retrospective } \\
\text { non-rand- } \\
\text { omized }\end{array}$ & 538 & $\begin{array}{r}36 \text { years } \\
(6-91)\end{array}$ & 376 & 97 & 0.70 & 0.86 & 5.06 & 0.35 \\
\hline $\begin{array}{l}\text { Käser et al. } \\
\text { [34] }\end{array}$ & $\begin{array}{l}\text { Retrospective } \\
\text { non-rand- } \\
\text { omized }\end{array}$ & 1073 & $\begin{array}{r}22 \text { years } \\
(5-92)\end{array}$ & 725 & 155 & 0.38 & 0.78 & 1.71 & 0.8 \\
\hline $\begin{array}{l}\text { Atahan et al. } \\
\text { [35] }\end{array}$ & $\begin{array}{l}\text { Retrospective } \\
\text { non-rand- } \\
\text { omized }\end{array}$ & 351 & $\begin{array}{l}31 \text { years } \\
(18-83)\end{array}$ & 302 & 45 & 0.80 & 0.84 & 4.9 & 0.24 \\
\hline $\begin{array}{l}\text { Hong et al. } \\
\text { [36] }\end{array}$ & $\begin{array}{l}\text { Retrospective } \\
\text { non-rand- } \\
\text { omized }\end{array}$ & 977 & 31 years & 732 & 245 & 0.32 & 0.84 & 2.01 & 0.81 \\
\hline $\begin{array}{l}\text { McGowan } \\
\text { et al. [37] }\end{array}$ & $\begin{array}{l}\text { Retrospective } \\
\text { non-rand- } \\
\text { omized }\end{array}$ & 1271 & - & 1053 & 154 & 0.55 & 0.90 & 5.76 & 0.50 \\
\hline
\end{tabular}


medication was excluded. Septic shock with subsequent ischemic injury to the hepatocytes has not occurred in any of them. The explanation for this hyperbilirubinemia associated with complicated appendicitis is circulating endotoxin related to the appendiceal infection. As explained in literature, in appendicitis, elevated intraluminal pressure and ischemic necrosis of mucosa causes tissue gangrene or perforation. This is accompanied by bacterial cytotoxin facilitated progressive bacterial invasion. This elevated load of bacteria causes direct invasion or translocation into the portal system. Direct invasion of bacteria into the hepatic parenchyma interferes with the bilirubin excretion into the bile canaliculi biochemically rather than by any obstructive pathway [27].

More over in this present study pre-operative mean total bilirubin level in complicated appendicitis cases came down from $1.39 \mathrm{mg} / \mathrm{dl}$ (uncomplicated group had pre-operative mean of $0.79 \mathrm{mg} / \mathrm{dl}$ ) to $0.69 \mathrm{mg} / \mathrm{dl} \mathrm{dur-}$ ing post-operative evaluation on 7th post operative day, which was equal to those having uncomplicated appendicitis after similar duration. So it was clear that the hyperbilirubinemia occurred due to complicated appendicitis only. No previous studies had estimated this normal serum bilirubin level in postoperative follow up period (Table 2).

In search of relationship of different parameters with occurrence of complicated acute appendicitis, the present study revealed that greater duration of pain, higher Alvarado score, pyrexia are associated with more chances of gangrenous or perforated appendicitis. USG scan is also helpful in predicting complicated appendicitis. The mean outer appendix diameter was $9.71 \mathrm{~mm}$ in case of complicated appendicitis. Presence of fecolith and periappendix collection were also associated with increased chances of complicated appendicitis. Summary of all parameters from present study is depicted in Table 9.

So, hyperbilirubinemia is possible in complicated acute appendicitis.

There were some limitations of this study also, like-

1. Study population was limited to a specific geographical area. So to study the universal nature of the relationship between study variables, multi center trial should be done. Results of this study should be corroborated by larger studies.

2. Information regarding use of antibiotics before admission was not available in 3 (uncomplicated) cases.

3. Relationship was found between increase in total bilirubin level and complicated appendicitis in logistic regression analysis but supplementing them with other parameters along with the total bilirubin level
Table 9 Summary of all parameters from present study

\begin{tabular}{|c|c|c|c|c|}
\hline Parameter & Type of appendicitis & Mean & SD & $p$ value \\
\hline \multirow[t]{2}{*}{ AGE (years) } & Uncomplicated & 26.81 & 13.22 & $<0.05$ \\
\hline & Complicated & 16.48 & 14.90 & \\
\hline \multirow[t]{2}{*}{ Total bilirubin (mg/dl) } & Uncomplicated & 0.79 & 0.16 & $<0.05$ \\
\hline & Complicated & 1.39 & 0.26 & \\
\hline \multirow[t]{2}{*}{ Direct bilirubin (mg/dl) } & Uncomplicated & 0.43 & 0.1 & $<0.05$ \\
\hline & Complicated & 0.72 & 0.13 & \\
\hline \multirow{2}{*}{$\begin{array}{l}\text { Indirect bilirubin (mg/ } \\
\text { dl) }\end{array}$} & Uncomplicated & 0.36 & 0.08 & $<0.05$ \\
\hline & Complicated & 0.66 & 0.14 & \\
\hline \multirow[t]{2}{*}{$\mathrm{ALP}(\mathrm{mg} / \mathrm{dl})$} & Uncomplicated & 126.02 & 6.79 & $>0.05$ \\
\hline & Complicated & 125.85 & 7.11 & \\
\hline \multirow[t]{2}{*}{ AST (mg/dl) } & Uncomplicated & 33.7 & 3.05 & $>0.05$ \\
\hline & Complicated & 32.88 & 3.38 & \\
\hline \multirow[t]{2}{*}{$\mathrm{ALT}(\mathrm{mg} / \mathrm{dl})$} & Uncomplicated & 33.34 & 2.76 & $>0.05$ \\
\hline & Complicated & 32.77 & 2.52 & \\
\hline \multirow[t]{2}{*}{ Alvarado score (1-10) } & Uncomplicated & 7.25 & 0.71 & $<0.05$ \\
\hline & Complicated & 8.5 & 0.77 & \\
\hline \multirow[t]{2}{*}{ Duration of pain (hours) } & Uncomplicated & 9.0 & 5.12 & $<0.05$ \\
\hline & Complicated & 20.2 & 1.49 & \\
\hline \multirow[t]{2}{*}{ Temparature ( $\left.{ }^{\circ} \mathrm{F}\right)$} & UNCOMPLICATED & 98.02 & 1.42 & $<0.05$ \\
\hline & Complicated & 99 & 1.47 & \\
\hline \multirow{2}{*}{$\begin{array}{l}\text { Appendix diameter } \\
(\mathrm{mm})\end{array}$} & Uncomplicated & 6.64 & 0.69 & $<0.05$ \\
\hline & Complicated & 9.71 & 1.27 & \\
\hline
\end{tabular}

will diagnose the complicated appendicitis more efficiently.

\section{Conclusion}

This is to conclude that Serum Total Bilirubin level estimation, which is a simple, cheap and easily available laboratory test, can be added to the routine investigations in clinically suspected cases of acute appendicitis. The rise in serum bilirubin level in subjects with acute appendicitis should be considered as having higher probability of complication (gangrene or perforation). Together with clinical findings and other routine laboratory tests, presence of serum hyperbilirubinemia may help in managing subjects with complicated acute appendicitis earlier. The role of serum hyperbilirubinemia, as a new diagnostic marker of complicated appendicitis, may be of particular help in

1. In surgical resource poor areas (like in ships, mountains, remote areas) suspected appendicitis cases with elevated serum bilirubin level should seek early surgical help.

2. In atypical presentation of acute appendicitis (like in retrocecal appendicitis, retroperitoneal appendicitis) 
hyperbilirubinemia should raise suspicion of complications.

Further studies may be carried out to assess the usefulness of hyperbilirubinemia as a diagnostic marker in acute complicated appendicitis with certain situations, like

1. In case of advanced pregnancy (atypical location of appendix).

2. In case of doubtful condition regarding appendicular lump formation and lack of confirmatory radiological facility, presence of serum hyperbilirubinemia may point towards complicated appendicitis and should necessitate surgical intervention.

3. In immunosuppressive condition (like transplant subjects, subjects on chemotherapy, AIDS, immunosuppressive drugs users), diabetic subjects with masked presentation of acute appendicitis, presence of hyperbilirubinemia may nessecitate surgical intervention.

\section{Abbreviations}

USG: Ultra-sonography; MDCT: Multi-detector computed tomography; CRP: C reactive protein; OPD: Out patient department; PPV: Positive predictive value; NPV: Negative predictive value.

\section{Acknowledgements}

None.

\section{Authors' contributions}

All investigations, data collections, data analysis, manuscript writing was done by SB, who is also the corresponding author. NM provided scientific knowledge and helped in correcting the manuscript. All authors have read and approved the final manuscript.

\section{Funding}

No funding source/grant was available.

\section{Availability of data and materials}

The datasets used and/or analysed during the current study are available from the corresponding author on reasonable request.

\section{Ethics approval and consent to participate}

Obtained from the Institutional Ethics Committee, Bankura Sammilani Medical College and Hospial, Bankura, West Bengal, India. Approval letter (The committee's reference number was BSMC/Aca/23 dated 02.01.18) is available for review by the editor of the journal. Written consents from individual subjects were also obtained. Written informed consent for participation in the study were obtained from the parents or guardians, where participants were children (under 16 years old).

\section{Consent to publication}

Not applicable.

\section{Competing interests}

The authors declare that they have no competing interests.

\section{Author details}

${ }^{1}$ Department of General Surgery, Bankura Sammilani Medical College and Hospital, Bankura, West Bengal 722102, India. ${ }^{2}$ Kathghara Lane, Sonatuli, PO, Hooghly, West Bengal 712103, India.

Received: 8 January 2020 Accepted: 14 January 2021

Published online: 28 January 2021

\section{References}

1. Whitehead MW, Hainsworth I, Kingham JG. The causes of obvious jaundice in South West Wales: perceptions versus reality. Gut. 2001;48(3):409-13.

2. Kumari S, Bhatnagar S, Khanna C, Sethi T, Mullick DN. Neonatal jaundice: association with neonatal septicemia. Indian Pediatr. 1987;24(5):433-5.

3. Wray CJ, Kao LS, Millas SG, et al. Acute appendicitis: controversies in diagnosis and management. Curr Probl Surg. 2013;50:54-86.

4. Addiss DG, Shaffer N, Fowler BS, Tauxe RV. The epidemiology of appendicitis and appendectomy in the United States. Am J Epidemiol. 1990;132:910-25.

5. Humes DJ, Simpson J. Acute appendicitis. BMJ. 2006:333(7567):530-4. https://doi.org/10.1136/bmj.38940.664363.AE.

6. Kang JY, Hoare J, Majeed A, Williamson RCN, Maxwell JD. Decline in admission rates for acute appendicitis in England. Br J Surg. 2003:90(12):1586-92.

7. Estrada JJ, Petrosyan M, Barnhart J, Tao M, Sohn H, Towfigh S, et al. Hyperbilirubinemia in appendicitis: a new predictor of perforation. J Gastrointest Surg. 2007;11:714-8.

8. Livingston EH, Woodward WA, Sarosi GA, Haley RW. Disconnect between incidence of nonperforated and perforated appendicitis: implications for pathophysiology and management. Ann Surg. 2007;245:886-92.

9. Petroianu A. Diagnosis of acute appendicitis. Int J Surg. 2012;10(3):115-9. https://doi.org/10.1016/j.ijsu.2012.02.006.

10. Afrand M, Modaresi V. Unusual presentation of a perforated appendicitis in a four-year-old girl - a case report from Yazd. Iran Electron Phys. 2014;6(2):788-93. https://doi.org/10.14661/2014.788-793.

11. Andersson R, Lambe M, Bergström R. Fertility patterns after appendicectomy: historical cohort study. BMJ. 1999;318(7189):963-7.

12. Hawkins JD, Thirlby RC. The accuracy and role of cross-sectional imaging in the diagnosis of acute appendicitis. Adv Surg. 2009;43:13-22.

13. Ghimire $P$, Thapa $P$, Yogi $N$, et al. Role of serum bilirubin as a marker of acute gangrenous appendicitis. Nepal J Med Sci. 2012;1(2):89-92.

14. Hoffmann J, Rasmussen OO. Aids in the diagnosis of acute appendicitis. Br J Surg. 1989;76:774-9.

15. Alvarado A. A practical score for early diagnosis of acute appendicitis. Ann Emerg Med. 1986;15(5):557-64.

16. Syed Raj R. Evaluation of hyperbilirubinemia in acute appendicitis. Int J Contemp Med Res. 2018;5(10):J13-6.

17. Parks NA, Schroeppel TJ. Update on imaging for acute appendicitis. Surg Clin North Am. 2011;91:141-54.

18. Rettenbacher T, Hollerweger A, Gritzmann N, et al. Appendicitis: should diagnostic imaging be performed if the clinical presentation is highly suggestive of the disease? Gastroenterology. 2002;123(4):992-8.

19. Pickhardt PJ, Lawrence EM, Pooler BD, Bruce RJ. Diagnostic performance of multidetector computed tomography for suspected acute appendicitis. Ann Intern Med. 2011;154:789-96.

20. Kalan M, Talbot D, Cunliffe WJ, Rich AJ. Evaluation of the modified Alvarado score in the diagnosis of acute appendicitis: a prospective study. Ann R Coll Surg Engl. 1994;76:418-9.

21. Escriba A, Gamell AM, Fernandez Y, Quintillá JM, Cubells CL. Prospective validation of two systems of classification for the diagnosis of acute appendicitis. Pediatr Emerg Care. 2011;27:165-9.

22. Chong CF, Thien A, Mackie AJ, Tin AS, Tripathi S, Ahmad MA. Comparison of RIPASA and Alvarado scores for the diagnosis of acute appendicitis. Singapore Med J. 2011;52:340-5.

23. Raahave D, Christensen E, Moeller H, Kirkeby LT, Loud FB, Knudsen LL. Origin of acute appendicitis: fecal retention in colonic reservoirs: a case control study. Surg Infect. 2007;8:55-62.

24. Nitecki S, Karmeli R, Sarr MG. Appendiceal calculi and fecaliths as indications for appendectomy. Surg Gynecol Obstet. 1990;171:185-8. 
25. Thadepalli H, Mandal AK, Chuah SK, Lou MA. Bacteriology of the appendix and the ileum in health and appendicitis. Am Surg. 1991;57:317-22.

26. Swidsinski A, Dorffel Y, Loening-Baucke $V$, et al. Acute appendicitis is characterised by local invasion with Fusobacterium nucleatum/necrophorum. Gut. 2011;60:34-40.

27. Bennion RS, Baron EJ, Thompson JE, et al. The bacteriology of gangrenous and perforated appendicitis-revisited. Ann Surg. 1990;211:165-71.

28. Wang P, Ayala A, Ba ZF, et al. Tumor necrosis factor-alpha produces hepatocellular dysfunction despite of normal cardiac output and hepatic microcirculation. Am J Physiol Gastrointet Liver Physiol. 1993;265:126-32.

29. Cheng CW, Lin HS, Ye JJ, Yang CC, Chiang PC, Wu TS, et al. Clinical significance of and outcomes for Bacteroides fragilis bacteremia. J Microbiol Immunol Infect. 2009:42:243-50.

30. Prystowsky JB, Pugh CM, Nagle AP. Current problems in surgery. Appendicitis. Curr Probl Surg. 2005;42:688-742.

31. Emmanuel A, Murchan P, Wilson I, Balfe P. The value of hyperbilirubinaemia in the diagnosis of acute appendicitis. Ann R Coll Surg Engl. 2011;93:213-7.

32. Khan S. Elevated serum bilirubin in acute appendicitis: a new diagnostic tool. Kathmandu Univ Med J. 2008:6:161-5.

33. Sand M, Bechara FG, Holland-Letz T, Sand D, Mehnert G, Mann B. Diagnostic value of hyperbilirubinemia as a predictive factor for appendiceal perforation in acute appendicitis. Am J Surg. 2009;198:193-8.
34. Käser SA, Fankhauser G, Willi N, Maurer CA. C-reactive protein is superior to bilirubin for anticipation of perforation in acute appendicitis. Scand J Gastroenterol. 2010;45:885-92.

35. Atahan K, Üreyen O, Aslan E, Deniz M, Çökmez A, Gür S, et al. Preoperative diagnostic role of hyperbilirubinaemia as a marker of appendix perforation. J Int Med Res. 2011;39:609-18.

36. Hong YR, Chung CW, Kim JW, Kwon Cl, Ahn DH, Kwon SW, et al. Hyperbilirubinemia is a significant indicator for the severity of acute appendicitis. J Korean Soc Coloproctol. 2012:28:247-52.

37. McGowan DR, Sims HM, Zia K, Uheba M, Shaikh IA. The value of biochemical markers in predicting a perforation in acute appendicitis. ANZ J Surg. 2013;83:79-83.

38. Berg CL, Crawford J, Gollan JL. Bilirubin metabolism and the pathophysiology of jaundice. In: Sorrell MF, Schiff ER, Maddrey WC, editors. Schiff's diseases of the liver. Philadelphia: Lippincott-Raven; 1999.

\section{Publisher's Note}

Springer Nature remains neutral with regard to jurisdictional claims in published maps and institutional affiliations.
Ready to submit your research? Choose BMC and benefit from:

- fast, convenient online submission

- thorough peer review by experienced researchers in your field

- rapid publication on acceptance

- support for research data, including large and complex data types

- gold Open Access which fosters wider collaboration and increased citations

- maximum visibility for your research: over 100M website views per year

At BMC, research is always in progress.

Learn more biomedcentral.com/submissions 